NASA/TM-2010-216262

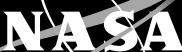

High-Efficiency K-Band Space Traveling-Wave Tube Amplifier for Near-Earth High Data Rate Communications

Rainee N. Simons and Dale A. Force

Glenn Research Center, Cleveland, Ohio

Paul C. Spitsen, William L. Menninger, Neal R. Robbins, Daniel R. Dibb, and Phillip C. Todd L-3 Communications Electron Technologies, Inc., Torrance, California 


\section{NASA STI Program . . . in Profile}

Since its founding, NASA has been dedicated to the advancement of aeronautics and space science. The NASA Scientific and Technical Information (STI) program plays a key part in helping NASA maintain this important role.

The NASA STI Program operates under the auspices of the Agency Chief Information Officer. It collects, organizes, provides for archiving, and disseminates NASA's STI. The NASA STI program provides access to the NASA Aeronautics and Space Database and its public interface, the NASA Technical Reports Server, thus providing one of the largest collections of aeronautical and space science STI in the world. Results are published in both non-NASA channels and by NASA in the NASA STI Report Series, which includes the following report types:

- TECHNICAL PUBLICATION. Reports of completed research or a major significant phase of research that present the results of NASA programs and include extensive data or theoretical analysis. Includes compilations of significant scientific and technical data and information deemed to be of continuing reference value. NASA counterpart of peer-reviewed formal professional papers but has less stringent limitations on manuscript length and extent of graphic presentations.

- TECHNICAL MEMORANDUM. Scientific and technical findings that are preliminary or of specialized interest, e.g., quick release reports, working papers, and bibliographies that contain minimal annotation. Does not contain extensive analysis.

- CONTRACTOR REPORT. Scientific and technical findings by NASA-sponsored contractors and grantees.
- CONFERENCE PUBLICATION. Collected papers from scientific and technical conferences, symposia, seminars, or other meetings sponsored or cosponsored by NASA.

- SPECIAL PUBLICATION. Scientific, technical, or historical information from NASA programs, projects, and missions, often concerned with subjects having substantial public interest.

- TECHNICAL TRANSLATION. Englishlanguage translations of foreign scientific and technical material pertinent to NASA's mission.

Specialized services also include creating custom thesauri, building customized databases, organizing and publishing research results.

For more information about the NASA STI program, see the following:

- Access the NASA STI program home page at http://www.sti.nasa.gov

- E-mail your question via the Internet to help@ sti.nasa.gov

- Fax your question to the NASA STI Help Desk at 443-757-5803

- Telephone the NASA STI Help Desk at 443-757-5802

- Write to: NASA Center for AeroSpace Information (CASI) 7115 Standard Drive Hanover, MD 21076-1320 
NASA/TM-2010-216262

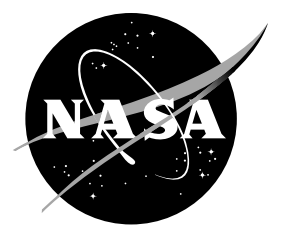

\section{High-Efficiency K-Band Space Traveling-Wave Tube Amplifier for Near-Earth High Data Rate Communications}

Rainee N. Simons and Dale A. Force

Glenn Research Center, Cleveland, Ohio

Paul C. Spitsen, William L. Menninger, Neal R. Robbins, Daniel R. Dibb, and Phillip C. Todd L-3 Communications Electron Technologies, Inc., Torrance, California

Prepared for the

2010 International Microwave Symposium

sponsored by the Institute of Electrical and Electronics Engineers

Anaheim, California, May 23-28, 2010

National Aeronautics and

Space Administration

Glenn Research Center

Cleveland, Ohio 44135 


\section{Acknowledgments}

The authors would like to thank T.T. Peterson and T.J. Kacpura, NASA Glenn Research Center Program Managers for their support for the NASA's Lunar Reconnaissance Orbiter (LRO) and Communications, Navigation and Networking

Reconfigurable Testbed (CoNNeCT) traveling-wave tube amplifier (TWTA) development efforts, respectively.

Trade names and trademarks are used in this report for identification only. Their usage does not constitute an official endorsement, either expressed or implied, by the National Aeronautics and Space Administration.

Level of Review: This material has been technically reviewed by technical management.

Available from

NASA Center for Aerospace Information 7115 Standard Drive

Hanover, MD 21076-1320
National Technical Information Service 5301 Shawnee Road Alexandria, VA 22312

Available electronically at http://gltrs.grc.nasa.gov 


\title{
High-Efficiency K-Band Space Traveling-Wave Tube Amplifier for Near-Earth High Data Rate Communications
}

\author{
Rainee N. Simons and Dale A. Force \\ National Aeronautics and Space Administration \\ Glenn Research Center \\ Cleveland, Ohio 44135

\begin{abstract}
Paul C. Spitsen, William L. Menninger, Neal R. Robbins, Daniel R. Dibb, and Phillip C. Todd
L-3 Communications Electron Technologies, Inc.

Torrance, California 90509
\end{abstract}

\begin{abstract}
The RF performance of a new K-Band helix conduction cooled traveling-wave tube amplifier (TWTA) is presented in this paper. A total of three such units were manufactured, tested and delivered. The first unit is currently flying onboard NASA's Lunar Reconnaissance Orbiter (LRO) spacecraft and has flawlessly completed over 2000 orbits around the Moon. The second unit is a proto-flight model. The third unit will fly onboard NASA's International Space Station (ISS) as a very compact and lightweight transmitter package for the Communications, Navigation and Networking Reconfigurable Testbed (CoNNeCT), which is scheduled for launch in 2011. These TWTAs were characterized over the frequencies 25.5 to $25.8 \mathrm{GHz}$. The saturated RF output power is $>40 \mathrm{~W}$ and the saturated $\mathrm{RF}$ gain is $>46 \mathrm{~dB}$. The saturated AM-to-PM conversion is $3.5 \% \mathrm{~dB}$ and the small signal gain ripple is $0.46 \mathrm{~dB}$ peak-to-peak. The overall efficiency of the TWTA, including that of the electronic power conditioner (EPC) is as high as 45 percent.
\end{abstract}

\section{Introduction}

The Lunar Reconnaissance Orbiter (LRO) is the first mission in NASA's Vision for Space Exploration, a plan to return to the Moon and then to travel to Mars and beyond. The LRO objectives are to find safe landing sites, locate potential resources, characterize the radiation environment, and demonstrate new technology (Ref. 1). NASA desires to transmit to Earth the planetary science data and video images of the Moon from the LRO at much higher data rates than the Apollo missions. The higher data rate requires higher power microwave amplifier. The amplifier has to have high efficiency since the DC power onboard the LRO is limited. In addition, the amplifier has to have very high reliability since the LRO operates in a harsh environment with high radiation and extreme temperatures, which extends over two years.

Vacuum electronics based devices for space applications such as helix traveling wave tube amplifiers (TWTAs) have demonstrated high on-orbit reliability at microwave frequencies (Ref. 2). In addition, TWTAs can deliver much higher RF output power with higher efficiency at KBand/Ka-Band frequencies than MMIC based solid-state power amplifiers (SSPAs) (Refs. 3 and 4).

In this paper, we present the RF performance characteristics of a new K-Band helix conduction cooled space traveling-wave tube amplifier (TWTA). A total of three such units were manufactured and are fully compliant with the required specifications. The first unit is currently flying onboard the NASA's Lunar Reconnaissance Orbiter (LRO) spacecraft. A photograph of the fully packaged LRO TWT and electronic power conditioner (EPC) is shown in Figure 1. The second unit was set aside as a proto-flight model and subjected to higher degree of mechanical shock and vibrations to evaluate the performance margins. The plan is to fly this unit as a spare on a future mission. The third unit will fly onboard NASA's International Space Station (ISS) as a very compact and lightweight transmitter package for the Communications, Navigation and Networking Reconfigurable Testbed (CoNNeCT), which is scheduled for launch in 2011. The CoNNeCT will investigate reprogrammable radio technology for use during space missions. This investigation will advance a common, software defined radio (SDR) architecture standard for future use on long duration space exploration missions. In addition, CoNNeCT will demonstrate communications from the ISS to the Tracking and Data Relay Satellite (TDRS) constellation at K-Band frequencies (Ref. 5). The above three amplifiers were manufactured by L-3 Communications Electron Technologies Inc., (ETI) under a contract from NASA Glenn Research Center (GRC). 


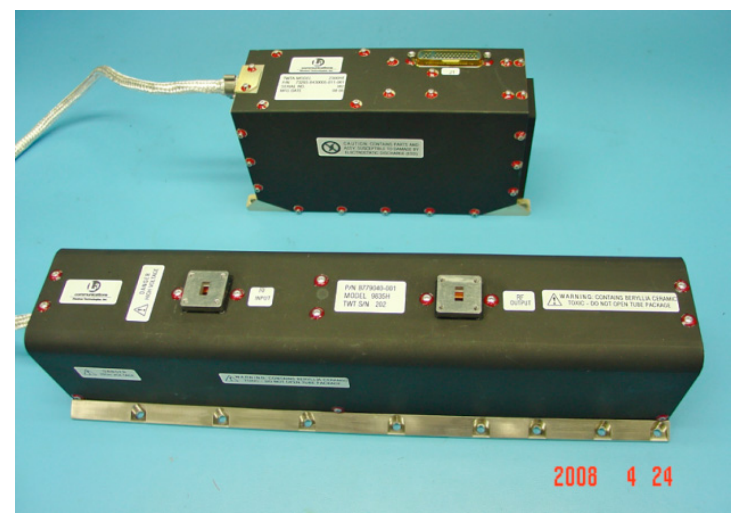

Figure 1.-Photograph of the LRO 40-W K-Band traveling-wave tube in a conduction cooled package attached by an umbilical power cord to an electronic power conditioner located in the background. The TWT input/output waveguide ports are WR-34.

\section{Traveling-Wave Tube Amplifier Design and Modeling}

Modern electromagnetic simulation/optimization software tools enabled the first pass design success. These software tools include the U.S. Naval Research Laboratory's CHRISTINE 3-D Code for high efficiency slow-wave interaction circuit and MICHELLE 3-D Code for multi-stage depressed collector design (Refs. 6 to 8). In addition, thermal modeling/simulation tools enabled the design of an efficient conduction cooled package (Ref. 9), which enhanced the power handling capability of TWT. Furthermore, advances in materials technology resulted in lightweight, temperature stable, high $\mathrm{BH}$ product samarium cobalt permanent magnets, which enabled focusing the electron beam. Moreover, advances in tungsten/osmium cathode technology resulted in cathode lifetimes exceeding 20 years in space (Ref. 10).

The baseline design for the LRO TWT was the model 999HA Ka-Band TWT (Ref. 9), which made use of WR28 waveguide-based input and output couplers. NASA recommended replacing the WR-28 waveguide couplers by larger WR-34 waveguide couplers in the LRO TWT. The advantages are: first, it eliminated the need for a tapered transition from WR-28 to WR-34 waveguide, reducing the overall height of the packaged TWT. Second, it resulted in thicker and larger diameter quartz windows for the vacuum seals inside the TWT, which provided additional strength to withstand mechanical shocks and vibrations and thus enhanced reliability. The proto-flight model TWT test results clearly demonstrated that this was the case. Third, the WR-34 waveguide operates across the frequency range of 22 to $33 \mathrm{GHz}$, which includes the frequency bands of interest for NASA's near-Earth communications. Thus with a minor design change in the helical slow wave circuit, the LRO TWT design can be optimized to meet future near-Earth NASA mission requirements without the need for requalification. The WR-34 waveguide lowered the total attenuation of the signal in the waveguide run between the TWT output and the antenna, which enhanced system efficiency.

\section{Requirements for the Lunar Reconnaissance Orbiter Traveling-Wave Tube Amplifier}

A brief set of requirements for the LRO TWT and EPC are presented in Tables I and II.

TABLE I.-EPC SPECIFICATIONS

\begin{tabular}{|l|c|}
\hline \multicolumn{1}{|c|}{ Parameter } & NASA specifications \\
\hline Voltage & $7 \mathrm{kV}$ \\
\hline Mass & $1300 \mathrm{gm}$ \\
\hline Size & $20(\mathrm{~L}) \times 7(\mathrm{~W}) \times 11(\mathrm{H}) \mathrm{cm}$ \\
\hline
\end{tabular}

TABLE II.-TWT SPECIFICATIONS

\begin{tabular}{|l|c|}
\hline \multicolumn{1}{|c|}{ Parameter } & NASA specifications \\
\hline Frequency band & 25.5 to $25.8 \mathrm{GHz}$ \\
\hline Output power, CW & $40 \mathrm{~W}$ min \\
\hline Saturated gain & $46 \mathrm{~dB}$ min \\
\hline Gain flatness (peak-to-peak) & $0.5 \mathrm{~dB}$ max \\
\hline Phase (peak-to-peak) & $8 \mathrm{deg} \max$ \\
\hline AM-to-PM & $4.5 \mathrm{deg} / \mathrm{dB}$ max \\
\hline VSWR & $2.0: 1 \mathrm{max}$ \\
\hline Overall efficiency & 44 percent min \\
\hline Overdrive & $+6 \mathrm{~dB}$ \\
\hline Mass & 1500 gm \\
\hline Size & $37(\mathrm{~L}) \times 9(\mathrm{~W}) \times 9(\mathrm{H}) \mathrm{cm}$ \\
\hline Input/Output ports & WR-34 waveguide \\
\hline Operating life/Mission life & $14 / 26$ months \\
\hline Environment & Lunar orbit \\
\hline
\end{tabular}

\section{Lunar Reconnaissance Orbiter Traveling-Wave Tube Amplifier and Performance Characteristics}

The TWT has a four-stage collector circuit for high efficiency. The collector circuit requires high voltages, which are provided by a standalone $7-\mathrm{kV}$ EPC, which is attached by an umbilical power cord to the TWT. The EPC is designed to operate from an unregulated spacecraft bus voltage in the range of 21.25 to $35 \mathrm{~V}$. The EPC has also a telemetry interface to the spacecraft bus, which provides the ON/OFF state of the TWTA as well 


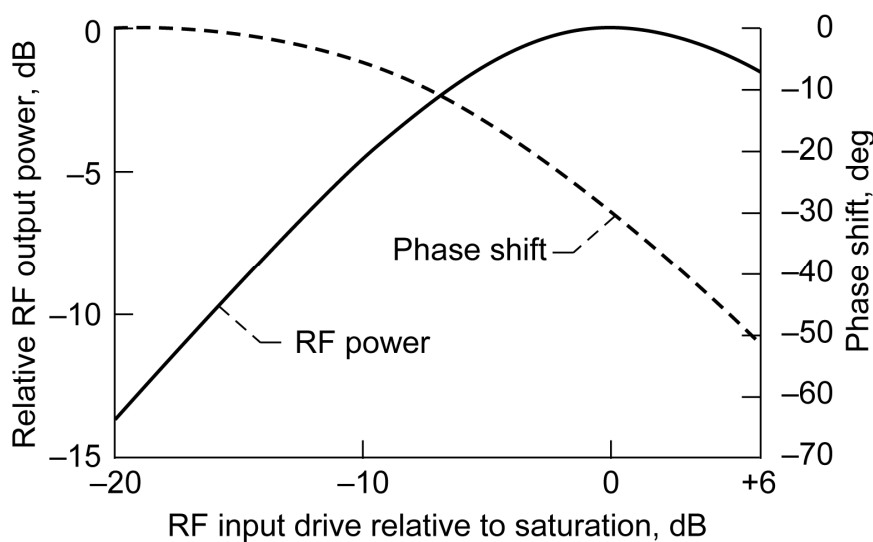

Figure 2.-Measured relative RF output power and phase shift as a function of the RF input drive relative to saturation at the center frequency of $25.65 \mathrm{GHz}$.

as the anode voltage, helix current and the RF output power. The construction of the EPC is explained in (Ref. 9). The TWTA was characterized over the frequencies 25.5 to $25.8 \mathrm{GHz}$ reserved for NASA's nearEarth communications. The measured data reported here are at a nominal spacecraft bus voltage of $31 \mathrm{~V}$ and ambient temperature of $25^{\circ} \mathrm{C}$.

\section{A. RF Output Power and Phase Shift}

The measured relative RF output power and phase shift as a function of the input drive level is presented in Figure 2. These measurements were carried out at the center frequency of $25.65 \mathrm{GHz}$. The output power at saturation is $46.22 \mathrm{~dB}$ or $41.88 \mathrm{~W}$, which exceeds the requirements of $40 \mathrm{~W}$. The phase shift through the amplifier, as the input drive is increased from small signal to saturation drive, is about $30^{\circ}$. The saturated gain compression is $6.09 \mathrm{~dB}$ and the saturated AM-to$\mathrm{PM}$ conversion is $3.5^{\circ} / \mathrm{dB}$.

\section{B. Saturated RF Gain}

The measured saturated RF gain as a function of the operating frequency range is presented in Figure 3. The saturated RF gain is about $49.25 \mathrm{~dB}$ across the operating frequency range and exceeds the requirements of $46 \mathrm{~dB}$.

\section{Saturated RF Output Power}

The measured saturated RF output power as a function of the operating frequency range is presented in Figure 4. The saturated RF output is about $46.25 \mathrm{~dB}$ or $42.17 \mathrm{~W}$ across the frequency range and exceeds the end of life (EOL) requirements of $40 \mathrm{~W}$.

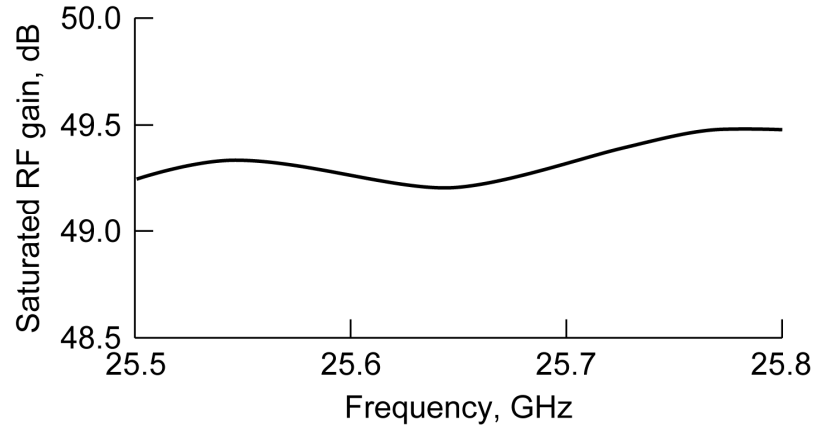

Figure 3.-Measured saturated RF gain as a function of frequency.

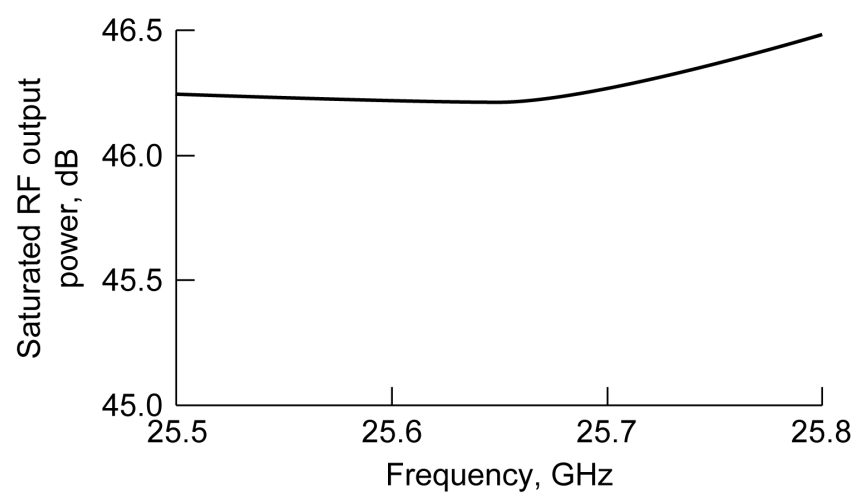

Figure 4.-Measured saturated RF output power as a function of frequency.

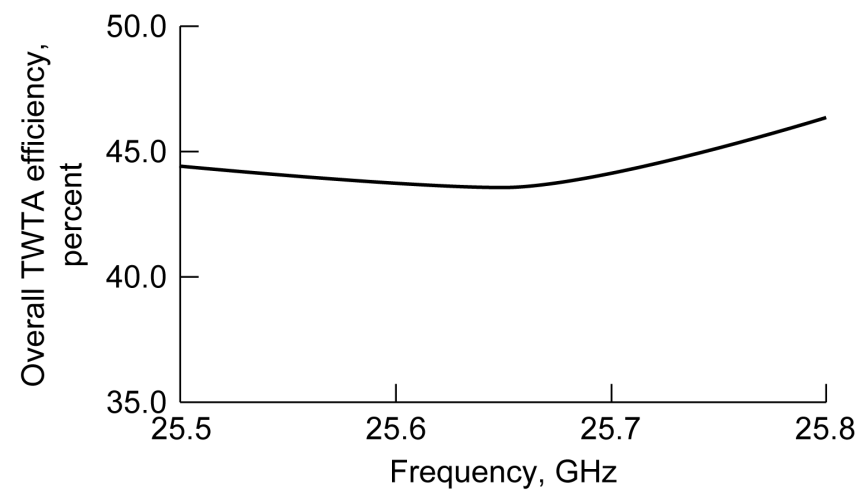

Figure 5.-Measured overall TWTA efficiency as a function of frequency.

\section{Overall Efficiency}

The efficiency of the TWT alone is 55.2 percent. However, when the efficiencies of the TWT and the EPC are combined, the overall efficiency of the TWTA is about 45 percent. The measured overall efficiency as a function of the operating frequency range is presented in Figure 5. The overall efficiency exceeds the requirements of 44 percent. 


\section{E. Noise Figure and Second Harmonic Level}

The measurements made at the center frequency of $25.65 \mathrm{GHz}$ show that the noise figure is $29.97 \mathrm{~dB}$ and the second harmonic level is $23.52 \mathrm{~dB}$ below the fundamental.

\section{F. Small Signal Gain and Phase Shift}

The measured small signal gain and residual phase shift as a function of the operating frequency range is presented in Figure 6. The small signal gain ripple is $0.46 \mathrm{~dB}$ peak-to-peak, which is within the requirements. The residual peak-to-peak small signal phase after subtracting the linear phase component corresponding to a group delay of $3.798 \mathrm{nS}$ is $2.02^{\circ}$, which is also within the requirements.

\section{G. Input/Output VSWR}

Figures 7(a) and (b) present the measured input/output return loss as a function of frequency. These results indicate that the input/output VSWR is in the range of 1.4 to 1.7 , over the operating frequency range of 25.5 to $25.8 \mathrm{GHz}$, which is within the requirements.

\section{H. Data Rate}

The LRO downlink data rate that this TWTA enables is on the order of $100 \mathrm{Mbps}$. The modulation is OQPSK. The total volume of data received on Earth per day is on the order of $450 \mathrm{~Gb}$. Compared with the previous Apollo missions to the Moon, the new technology offers several orders of magnitude improvement in data rates and volume.

\section{EMI/EMC}

The input filter in the EPC was designed, manufactured and implemented within the physical limitations of the EPC package. This filter did not adequately suppress the conducted emissions from the EPC to the bus. Hence, in order to meet the LRO requirements an external LC filter, which effectively reduced the nonconformance to zero, was designed, manufactured and inserted between the EPC and the bus.

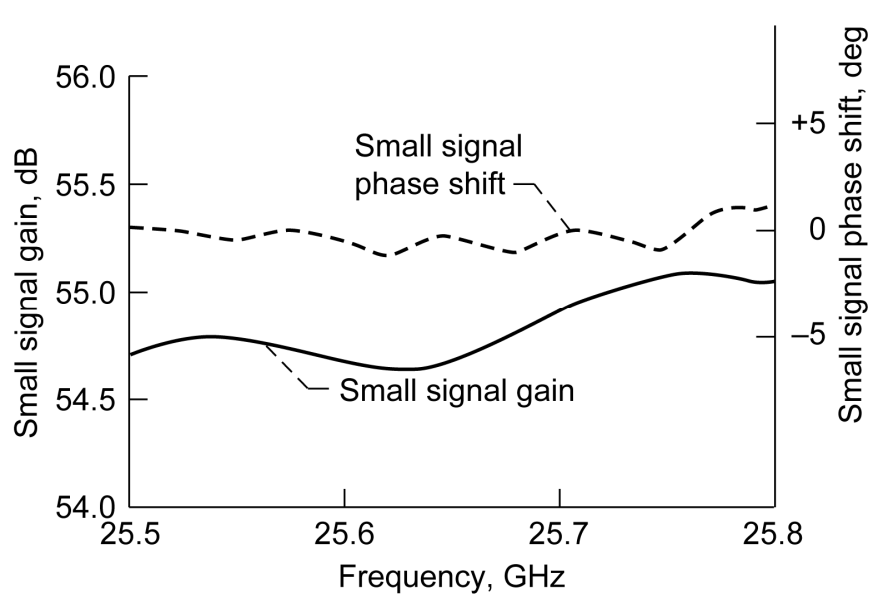

Figure 6.-Measured small signal gain and phase shift as a function of frequency.
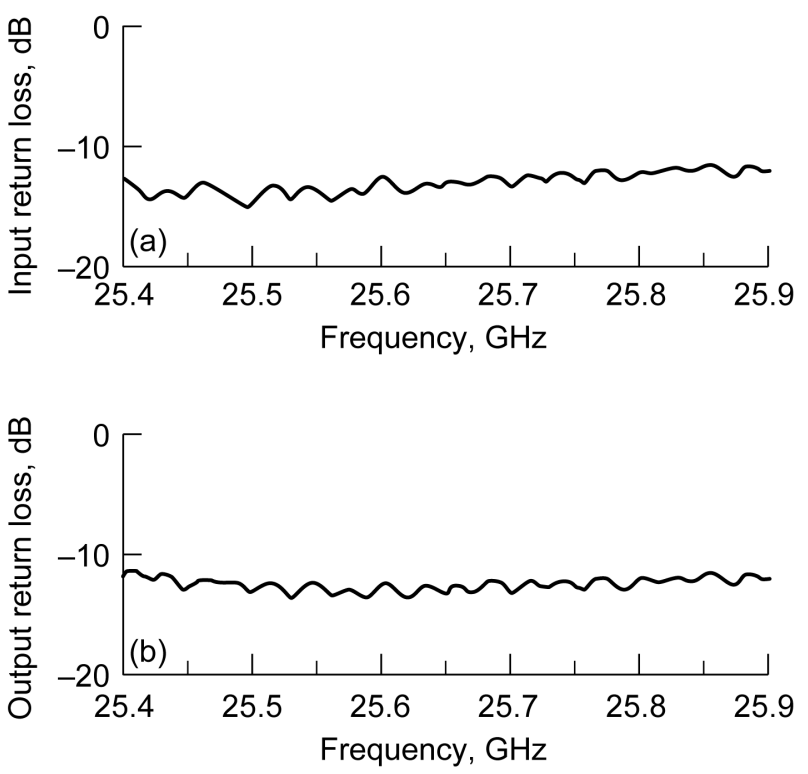

Figure 7.-Measured return loss as a function of frequency. (a) Input port (b) Output port. 


\section{Conclusions and Discussions}

The performance parameters of a state-of-the-art compact lightweight K-Band TWTA for NASA's LRO and the CoNNeCT are presented. The saturated RF output power exceeds $40 \mathrm{~W}$ and saturated RF gain exceeds $46 \mathrm{~dB}$. The saturated AM-to-PM conversion is $3.5^{\circ} \mathrm{dB}$ and the small signal gain ripple is $0.46 \mathrm{~dB}$ peakto-peak. The overall efficiency including that of the EPC is as high as 45 percent. The LRO downlink data rate that this TWTA enables is as high as $100 \mathrm{Mbps}$, which is several orders of magnitude higher than the Apollo mission. The mass and size of the TWT and the EPC are fully compliant with the specifications presented in Tables I and II.

The TWTA onboard the LRO spacecraft has flawlessly completed over 2000 orbits around the Moon since its launch in June 2009. An independent judging panel and the editors of the R\&D Magazine recognized the TWTA as one of the 100 most technologically significant products introduced in the past year and awarded it the 2009 R\&D 100 Award. In addition, the LRO was chosen as \#3 on Time's 50 Best Inventions of 2008. Furthermore, the December 2009 issue of Popular Science has named the LRO as one of the 100 Best Innovations of the year.

\section{References}

1. http://lunar.gsfc.nasa.gov/mission.html

2. E.F. Nicol, B.J. Mangus, and J.R. Grebliunas, "TWTA versus SSPA: Analysis update of the Boeing fleet on-orbit reliability data," 2008 IEEE International Vacuum Electronics Conference Digest, pp. 169-170, Monterey, CA, April 22-24, 2008.

3. R.N. Simons, J.D. Wilson, and D.A. Force, "High power and efficiency space traveling-wave tube amplifiers with reduced size and mass for NASA missions," 2008 IEEE MTT-S International Microwave Symposium Digest, pp. 319-322, Atlanta, GA, June 15-20, 2008.
4. R.N. Simons, E.G. Wintucky, J.D. Wilson, D.A. Force, "Ultra-high power and efficiency space traveling-wave tube amplifier power combiner with reduced size and mass for NASA missions," IEEE Trans. Microwave Theory Tech., vol. 57, no. 3, pp. 582-588, March 2009.

5. http://www.nasa.gov/mission_pages/station/science/ experiments/CoNNeCT.html

6. D. Chernin, T.M. Antonsen, Jr., B. Levush, and D.R. Whaley, "A three-dimensional multifrequency large signal model for helix traveling wave tubes," IEEE Trans. Electron Devices, vol. 48, no. 1, pp. 3-11, Jan. 2001.

7. D.K. Abe, B. Levush, T.M. Antonsen, Jr., D.R. Whaley and B.G. Danly, "Design of a linear C-band helix TWT for digital communications experiments using the CHRISTINE suite of large-signal codes," IEEE Trans. Plasma Science, vol. 30, no. 3, part 1, pp. 1053-1062, June 2002.

8. J.J. Petillo, E.M. Nelson, J.F. DeFord, N.J. Dionne, and B. Levush, "Recent developments to the MICHELLE 2-D/3-D electron gun and collector modeling code," IEEE Trans. Electron Devices, vol. 52, no. 5, pp. 742-748, May 2005.

9. W.L. Menninger, N.R. Robbins, D.R. Dibb, and D.E. Lewis, "Power flexible Ka-band traveling wave tube amplifiers of up to $250-\mathrm{W}$ RF for space communications," IEEE Trans. Electron Devices, vol. 54, no. 2, pp. 181-187, Feb. 2007.

10. J.D. Wilson, E.G. Wintucky, K.R. Vaden, D.A. Force, I.L. Krainsky, R.N. Simons, N.R. Robbins, W.L. Menninger, D.R. Dibb, and D.E. Lewis, "Advances in space traveling-wave tubes for NASA missions," Proc. IEEE, Special Issue on Technical Advances in Deep Space Communications \& Tracking: Part 1, vol. 95, no. 10, pp. 1958-1967, Oct. 2007. 


\begin{tabular}{|c|c|c|}
\hline \multicolumn{2}{|c|}{ REPORT DOCUMENTATION PAGE } & $\begin{array}{l}\text { Form Approved } \\
\text { OMB No. 0704-0188 }\end{array}$ \\
\hline \multicolumn{3}{|c|}{$\begin{array}{l}\text { The public reporting burden for this collection of information is estimated to average } 1 \text { hour per response, including the time for reviewing instructions, searching existing data sources, gathering and maintaining the } \\
\text { data needed, and completing and revieving the collection of information. Send comments regarding this burden estimate or any other aspect of this collection of information, including suggestions for reducing this } \\
\text { burden, to Department of Defense, Washington Headquarters Services, Directorate for Information Operations and Reports ( } 0704-0188,1215 \text { Jefferson Davis Highway, Suite } 1204 \text {, Arlington, VA } 22202-4302 \text {. } \\
\text { Respondents should be aware that notwithstanding any other provision of law, no person shall be subject to any penalty for failing to comply with a collection of information if it does not display a currently valid OME } \\
\text { control number. } \\
\text { PLEASE DO NOT RETURN YOUR FORM TO THE ABOVE ADDRESS. }\end{array}$} \\
\hline $\begin{array}{l}\text { 1. REPORT DATE (DD-MM-YYYY) } \\
01-03-2010\end{array}$ & $\begin{array}{l}\text { 2. REPORT TYPE } \\
\text { Technical Memorandum }\end{array}$ & 3. DATES COVERED (From - To) \\
\hline \multirow{3}{*}{\multicolumn{2}{|c|}{$\begin{array}{l}\text { 4. TITLE AND SUBTITLE } \\
\text { High-Efficiency K-Band Space Traveling-Wave Tube Amplifier for Near-Earth High Data } \\
\text { Rate Communications }\end{array}$}} & 5a. CONTRACT NUMBER \\
\hline & & 5b. GRANT NUMBER \\
\hline & & 5c. PROGRAM ELEMENT NUMBER \\
\hline \multirow{3}{*}{\multicolumn{2}{|c|}{$\begin{array}{l}\text { 6. AUTHOR(S) } \\
\text { Simons, Rainee, N.; Force, Dale, A.; Spitsen, Paul, C.; Menninger, William, L.; Robbins, } \\
\text { Neal, R.; Dibb, Daniel, R.; Todd, Phillip, C. }\end{array}$}} & 5d. PROJECT NUMBER \\
\hline & & 5e. TASK NUMBER \\
\hline & & $\begin{array}{l}\text { 5f. WORK UNIT NUMBER } \\
\text { WBS } 342556.06 .01 .10 .01 .02\end{array}$ \\
\hline \multicolumn{2}{|c|}{$\begin{array}{l}\text { 7. PERFORMING ORGANIZATION NAME(S) AND ADDRESS(ES) } \\
\text { National Aeronautics and Space Administration } \\
\text { John H. Glenn Research Center at Lewis Field } \\
\text { Cleveland, Ohio 44135-3191 }\end{array}$} & $\begin{array}{l}\text { 8. PERFORMING ORGANIZATION } \\
\text { REPORT NUMBER } \\
\text { E-17124-1 }\end{array}$ \\
\hline \multirow{2}{*}{\multicolumn{2}{|c|}{$\begin{array}{l}\text { 9. SPONSORING/MONITORING AGENCY NAME(S) AND ADDRESS(ES) } \\
\text { National Aeronautics and Space Administration } \\
\text { Washington, DC 20546-0001 }\end{array}$}} & $\begin{array}{l}\text { 10. SPONSORING/MONITOR'S } \\
\text { ACRONYM(S) } \\
\text { NASA }\end{array}$ \\
\hline & & $\begin{array}{l}\text { 11. SPONSORING/MONITORING } \\
\text { REPORT NUMBER } \\
\text { NASA/TM-2010-216262 }\end{array}$ \\
\hline \multicolumn{3}{|c|}{$\begin{array}{l}\text { 12. DISTRIBUTION/AVAILABILITY STATEMENT } \\
\text { Unclassified-Unlimited } \\
\text { Subject Category: } 17 \\
\text { Available electronically at http://gltrs.grc.nasa.gov } \\
\text { This publication is available from the NASA Center for AeroSpace Information, 443-757-5802 }\end{array}$} \\
\hline
\end{tabular}

\section{ABSTRACT}

The RF performance of a new K-Band helix conduction cooled traveling-wave tube amplifier (TWTA) is presented in this paper. A total of three such units were manufactured, tested and delivered. The first unit is currently flying onboard NASA's Lunar Reconnaissance Orbiter (LRO) spacecraft and has flawlessly completed over 2000 orbits around the Moon. The second unit is a proto-flight model. The third unit will fly onboard NASA's International Space Station (ISS) as a very compact and lightweight transmitter package for the Communications, Navigation and Networking Reconfigurable Testbed (CoNNeCT), which is scheduled for launch in 2011. These TWTAs were characterized over the frequencies 25.5 to $25.8 \mathrm{GHz}$. The saturated RF output power is $>40 \mathrm{~W}$ and the saturated RF gain is $>46 \mathrm{~dB}$. The saturated AM-toPM conversion is $3.5^{\circ} \mathrm{dB}$ and the small signal gain ripple is $0.46 \mathrm{~dB}$ peak-to-peak. The overall efficiency of the TWTA, including that of the electronic power conditioner (EPC) is as high as 45 percent.

15. SUBJECT TERMS

Telecommunications; Transmitters; Deep space network; Space communication; Satellite communications; Microwave transmission; Microwave amplifiers; Microwave tubes; Power amplifiers; Power conditioning; Power efficiency; Traveling wave tubes

\begin{tabular}{|c|c|c|c|c|c|}
\hline \multicolumn{3}{|c|}{ 16. SECURITY CLASSIFICATION OF: } & \multirow{2}{*}{$\begin{array}{l}\text { 17. LIMITATION OF } \\
\text { ABSTRACT } \\
\text { UU }\end{array}$} & \multirow{2}{*}{$\begin{array}{l}\text { 18. NUMBER } \\
\text { OF } \\
\text { PAGES } \\
11\end{array}$} & \multirow{2}{*}{$\begin{array}{l}\text { 19a. NAME OF RESPONSIBLE PERSON } \\
\text { STI Help Desk (email:help@ } \text { sti.nasa.gov) } \\
\text { 19b. TELEPHONE NUMBER (include area code) } \\
\text { 443-757-5802 }\end{array}$} \\
\hline $\begin{array}{l}\text { a. REPORT } \\
U\end{array}$ & $\begin{array}{l}\text { b. ABSTRACT } \\
U\end{array}$ & $\begin{array}{l}\text { c. THIS } \\
\text { PAGE } \\
\text { U }\end{array}$ & & & \\
\hline
\end{tabular}



